International Journal of Agriculture, Environment and Bioresearch

Vol. 5, No. 05; 2020

ISSN: 2456-8643

\title{
STUDY OF THE POTENTIAL DISTRIBUTION OF RARE AND ENDANGERED SPECIES OF THE EUPHORBIACEAE FAMILY OF CÔTE D'IVOIRE
}

\author{
YAO N'Guettia Francis ${ }^{1}$, KOFFI Kouao Jean ${ }^{1 *}$, TUO Fatou ${ }^{1}$, KONE Moussa ${ }^{1}$, ADAMA Bakayoko ${ }^{12}$, Jan \\ BOGAERT ${ }^{3}$ \\ ${ }^{1}$ Université Nangui Abrogoua, UFR-SN, 02 BP 801 Abidjan 02 (Côte d'Ivoire), www.univ-na.edu.ci \\ ${ }^{2}$ Centre Suisse de Recherches Scientifiques en Côte d'Ivoire, 01 BP 1303 Abidjan, https://www.csrs.ch/ \\ ${ }^{3}$ Université de Liège / Gembloux Agro-Bio Tech Unité Biodiversité et Paysage, Passage des Déportés, 2 , B-5030 \\ Gembloux (Belgique), http://www.gembloux.ulg.ac.be/biodiversite-et-paysage/contacts/
}

https://doi.org/10.35410/IJAEB.2020.5558

\begin{abstract}
The main objective of this study is to contribute to the knowledge of the species of the Euphorbiaceae family from Côte d'Ivoire. Specifically, this involves carrying out a floristic analysis of Euphorbiaceae from Côte d'Ivoire, determining the species with special statuses of the Euphorbiaceae family from Côte d'Ivoire and analyzing their potential distribution. The endangered species database (Aké Assi, 1988) and the IUCN Red List (2019) were used to identify species with special status. Quantum GIS software and the Maxent model were used for the realization of the potential distribution maps. Four special status species have been listed: Croton membranaceus Müll. Arg., Croton aubrevillei J. Léonard, Macaranga beillei Pan. and Sapium caterinum J. Léonard. The potential distribution map of Sclerocroton carterianus (J.Léonard) Kruijt \& Roebers, was not produced due to insufficient number of samples. Floristic analysis revealed that $75 \%$ of species are microphanerophytes, $50 \%$ are endemic to the forest block west of Togo, including Ghana, Côte d'Ivoire, Liberia, Sierra Leone, Guinea Bissau, Gambia and Senegal.
\end{abstract}

Keywords: Euphorbiaceae, Potential distribution, Biodiversity, Côte d'Ivoire.

\section{INTRODUCTION}

According to the Convention on Biological Diversity ISBN: 92-9225-129-5, two-thirds of the world's plant species are in danger of extinction due to increasing pressure from the human population, habitat modification, deforestation, overexploitation, pollution and the increasing impact of climate change. This phenomenon directly contributes to the loss of biological diversity and the decline of ecosystems around the world. Thus, West African ecosystems, the most diverse on the planet, with a high rate of endemism (Koffi et al., 2008), are unfortunately, like those of the world, subject to all kinds of pressure, hence its progressive degradation. The most common causes of this degradation are the felling of trees, shifting cultivation, the extension of family farming to industrial agriculture and intensive animal husbandry (Vroh Bi et 
al., 2011). In this context, particular priority is given to species with special status. In Côte d'Ivoire, according to the fifth national report on biological diversity in 2014, by 2020, surveys on the status of species with special status, their distribution and their ecology, the results of linkage to the management of conservation, and specific safeguard measures are implemented for $100 \%$ of the priority species identified. As a result, by 2020 , the extinction of known endangered species is avoided and their conservation status, especially those that are falling most in decline, is improved and maintained.

It is in this perspective that this study is oriented by using species of the family Euphorbiaceae. Indeed, the Euphorbiaceae family, considered to be one of the largest and most cosmopolitan families in the Angiosperms sub-phylum, includes around 10,000 species grouped into 300 genera worldwide (Haba, 2008).

In Côte d'Ivoire, it contains 160 taxa divided into 50 genera (Aké Assi, 2001).Also, the Euphorbiaceae family has within it various species with several importance observed in several fields, namely the industrial field (Aké Assi, 2001), the food sector (Edouard, 1974; Aké Assi, 2001), the medical field (Bouquet and Debray, 1974) and the ornamental domain (Aké Assi, 2001).

Thus, this preliminary study, comes as a contribution to the knowledge of the species of the Euphorbiaceae family of Ivory Coast in general. Specifically, it will be a question of (1) carrying out a floristic analysis on all the species of the Euphorbiaceae family recorded in Côte d'Ivoire, (2) of determining the rare and / or endangered species of this family and (3) analyze the potential distribution of these rare and endangered species of the Euphorbiaceae family from Côte d'Ivoire.

\section{MATERIAL AND METHODS}

\subsection{Material}

The biological material used in this work is mainly composed of species of the Euphorbiaceae family extracted from the SIG IVOIRE database (Gautier et al, 1999) and flora from Côte d'Ivoire (Aké Assi, 2001). Excel software is used to establish the list of species to be processed. The list of threatened species (Aké Assi, 1998) and the IUCN red list (2019) have made it possible to identify the species of Euphorbiaceae with special status. The QGIS software (Quantum GIS) Lyon version 2.12.3 and the MaxEnt (Maximum Entropy) model were used to produce maps of the potential distribution of species.

\subsection{Methods}

\subsubsection{Floristic analysis}

The floristic analysis made it possible to determine the number of genera, the number of species, the most important genera in terms of number of species, the most important species in number of samples. The list of species of the flora of Côte d'Ivoire (Aké Assi, 2001) made it possible to group the species according to their chorological type and their biological type. Indeed the chorological type can be defined as being the geographical distribution of the species. As for the biological type, it can be defined as the organization of plants according to the positioning of the survival organs during the unfavorable period. 


\subsubsection{Determination of threatened species of the Euphorbiaceae family}

The IUCN (2019) model was used to list Euphorbiaceae species according to the different IUCN threat categories in the database. In this same Euphorbiaceae database, the rare endemic species of Côte d'Ivoire according to Aké Assi $(1998,2010)$ were identified.

\subsubsection{Realization of potential distribution maps}

Potential distribution can be defined as the probable spatial distribution of a species. These models will provide a better understanding of the ecology of species and allow more reliable predictions. On the other hand, a region that has the appropriate set of biotic and abiotic factors and that is accessible to the species (through dispersal) constitutes the potential geographic distribution of the species (Soberon, 2007). The species to be modeled in this work are those with a particular status. A matrix with species and geographical coordinates was produced with the database of special status species. All these data, after having been transformed into csv format (separator, semi-colon), were submitted to the MaxEnt Species Distribution Modeling model (Phillips et al., 2004), version 3.3 for the realization of potential distribution maps. The environmental variables were obtained from Worldclim (Hijmans et al., 2005; http://www.worldclim.org/). They cover the period from 1950 to 2000 . The variables are the average precipitation, the minimum and maximum temperature and 19 bioclimatic variables (BIOCLIM: http://www.worldclim.org/bioclim.htm) which can have an influence on the distribution species (Table I). The software does 1000 iterations before predicting the potential areas of species, taking into account the environmental variables that are most critical for the species concerned. The use of bioclimatic variables for the realization of potential distribution maps is an advantage because they are independent of the degree of exploration. However, there are limits to identifying poorly sampled areas (Engler et al., 2004), as species with many samples will have a wider range compared to those with few samples. On the other hand, bioclimatic variables do not take into account anthropogenic factors and also abiotic factors (Hamilton and Taylor, 1991). So, to have meaningful results, we will realize the potential distribution of species with at least 10 samples.

Table I: BIOCLIM environmental variables used to generate the potential distribution maps (http://www.worldclim.org/bioclim.htm)

\begin{tabular}{|c|c|}
\hline & Bioclimatic variables \\
\hline Bio_1 & Annual Mean Temperature \\
\hline Bio_2 & $\begin{array}{l}\text { Mean Diurnal Range (Mean of monthly (max temp - min } \\
\text { temp)) }\end{array}$ \\
\hline Bio_3 & Isothermality $(\mathrm{BIO} 2 / \mathrm{BIO} 7)(\times 100)$ \\
\hline Bio_4 & Temperature Seasonality (standard deviation $\times 100$ ) \\
\hline Bio_5 & Max Temperature of Warmest Month \\
\hline Bio_6 & Min Temperature of Coldest Month \\
\hline Bio_7 & Temperature Annual Range (BIO5-BIO6) \\
\hline Bio_8 & Mean Temperature of Wettest Quarter \\
\hline Bio_9 & Mean Temperature of Driest Quarter \\
\hline
\end{tabular}




\begin{tabular}{|ll} 
Bio_10 & Mean Temperature of Warmest Quarter \\
Bio_11 & Mean Temperature of Coldest Quarter \\
Bio_12 & Annual Precipitation \\
Bio_13 & Precipitation of Wettest Month \\
Bio_14 & Precipitation of Driest Month \\
Bio_15 & Precipitation Seasonality (Coefficient of Variation) \\
Bio_16 & Precipitation of Wettest Quarter \\
Bio_17 & Precipitation of Driest Quarter \\
Bio_18 & Precipitation of Warmest Quarter \\
Bio_19 & Precipitation of Warmest Quarter \\
\hline
\end{tabular}

The prediction of habitats is obtained from the interpolation of the bioclimatic characteristics of each point of presence of the species. One of the parameters used to evaluate the predictive capacity of a model generated by MaxEnt is the AUC (Area Under Curve) which is the area under the ROC (Receiver Operating Characteristic) curve. AUC can then be interpreted as the likelihood that a randomly chosen point of presence is located in a raster cell with a greater probability of species occurrence than a randomly generated point (Phillips et al, 2006). The results obtained are useful for a better understanding of the ecology of the species and more reliable predictions. For Araújo et al. (2005), for a model generated by MaxEnt, recommend an interpretation of AUC (Table II).

For the finalization of the maps generated from the MaxEnt model, we used the extension files (asc) which present pixel maps then imported into the QGIS software (Quantum GIS) version Lyon 2.12.3 to establish the maps of potential distribution.

Table II: Validity of the MaxENT test according to the AUC values obtained (Araújo et al., 2005)

\begin{tabular}{|l|l|}
\hline Interpretations & Values \\
\hline Excellent & $1,00>$ AUC $>0,90$ \\
\hline Good & $0,80<$ AUC $<0,90$ \\
\hline Acceptable & $0,70<$ AUC $<0,80$ \\
\hline Bad & $0,60<$ AUC $<0,70$ \\
\hline Invalid & $0,50<$ AUC $<0,60$ \\
\hline
\end{tabular}


Vol. 5, No. 05; 2020

ISSN: $2456-8643$

\section{RESULTS}

\subsection{Floristic analysis}

\subsubsection{Description of the flora of Euphorbiaceae}

This study involved 1,430 samples collected from 1905 to 1999 by about 59 collectors and in almost 42 localities of Côte d'Ivoire. Thus, following the verification carried out, it turned out that some species of the Euphorbiaceae family have changed families. The different host families are Phyllanthaceae (43 species), Putranjivaceae (11 species), Pandaceae (2 species) and Urticaceae, Thymelaeaceae, Picrodendraceae (1 species each). Also, 22 species of the Euphorbiaceae family have gone into synonymy. Among them, we can cite: Acalypha racemosa Baill now Acalypha paniculata Miq; Croton lobatus L. now Astraea lobate Klotzsch etc.

After verifying the scientific names of the sampled species, it appears that the database at our disposal includes 38 genera, 102 species and 899 samples (Annex). The most represented genera are the genus Euphorbia (19 species) and the genus Croton (15 species). The least represented genus is Hura with only one species. The most harvested species are Mallotus oppositifolius (Geisler) Müll. Arg. and Mareya micrantha (Benth.) Muell. Arg. with 45 and 33 samples each, respectively. The least collected species is Tragia vogeliiKeay with a sample. Other species are moderately harvested and the number of their samples varies between 6 and 17. One can quote Tetrorchidium didymostemon (Baill.) Pax \& K. Hoffm. (17 samples), Manniophyton fulvum Müll. Arg. (14 samples), Micrococca mercurialis (L.) Benth. (6 samples).

\subsubsection{Chorological type}

Figure 1 shows that the Guineo-Congolese (GC) species are the most represented with $50 \%$ of all species. The other species are represented as follows: GC-SZ (22\%), GCW (13), SZ (11\%) and GCi (4\%). This last group which characterizes the endemic species of Côte d'Ivoire is represented by: Macaranga beillei Prain, Shirakiopsis aubrevillei (Léandri) Esser, Drypetes singroboensis Aké Assi, Tragia polygonoides Prai.

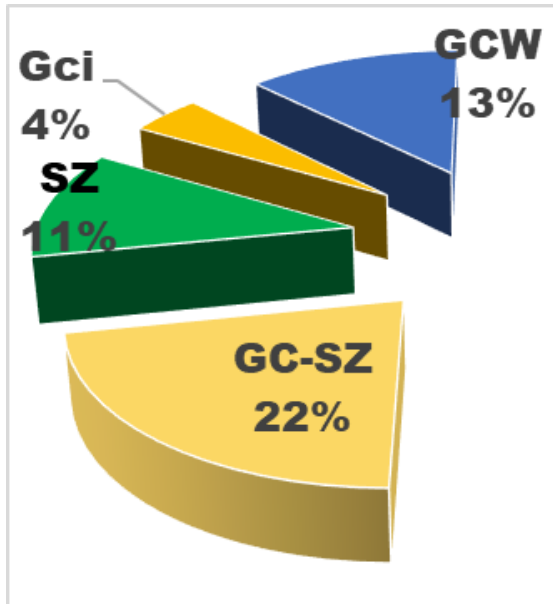


Figure 1: Chorological type of species of the family Euphorbiaceae

(GC: Guinean-Congolese;GC-SZ: Guinean-Congolese -Sudano-Zambezians;SZ: SudanoZambezians;GCW: endemic species of the forest block west of Togo, including Ghana, Ivory Coast, Liberia, Sierra Leone, Guinea Bissau, Gambia and Senegal;GCi: endemic species of Côte d'Ivoire).

\subsubsection{Biological type}

Floristic analysis revealed that microphanerophytes $(\mathrm{mp})$ are largely dominant with a rate of $44 \%$. Lianescent microphanerophytes Lmp (mp) are the weakest represented with a rate of $1 \%$ (figure 2).

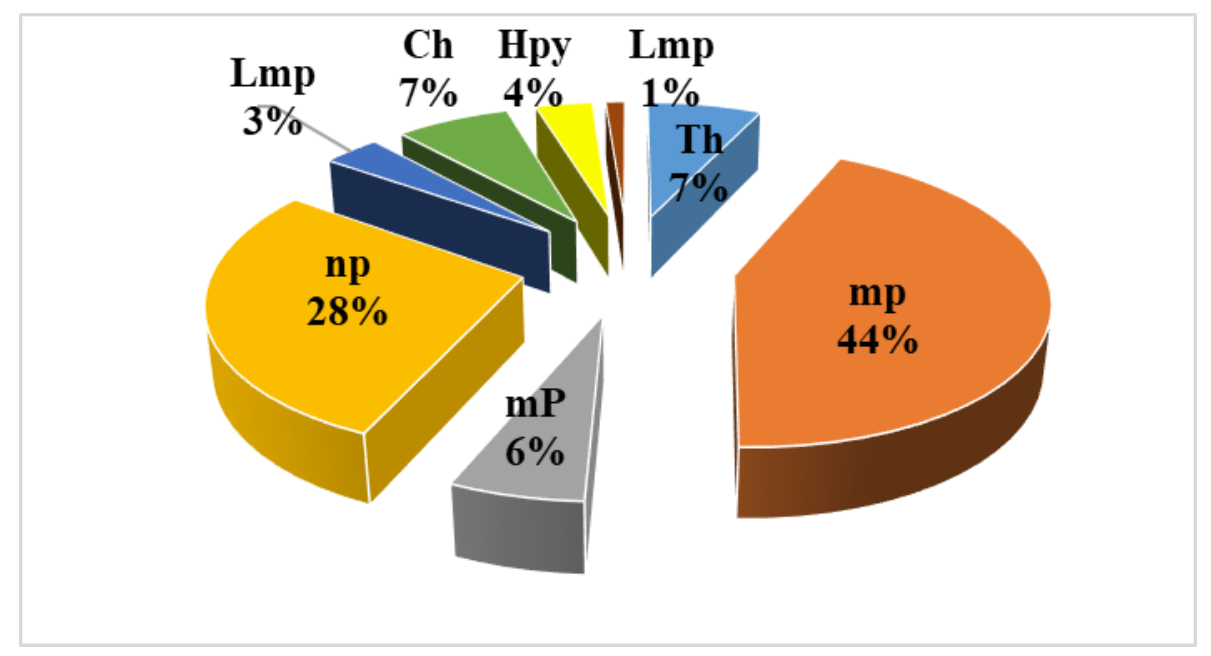

Figure 2: Biological type of species of the family Euphorbiaceae

(mp: microphanerophytes; np: nanophanerophytes; Lmp: lianescent microphanerophytes; Ch: Chaméphytes; Th: Therophytes; Lmp (mp): lianescent microphanerophytes, mP: mesophanerophyte; Hc: hemicryptophyte)

\subsubsection{Identification of threatened species}

Four species with special status have been listed. This is Croton membranaceus Müll. Arg., Sapium caterinum J. Léonard, Croton aubrevillei J. Léonard. And Macaranga beillei Pan. However, the potential distribution map of Sclerocroton carterianus (J.Léonard) Kruijt \& Roebers was not produced due to the insufficient number of samples ( 3 samples collected in the forests of Ningue, Teke and in the Botanical Garden of Adiopodoume). 


\subsection{Potential distribution of threatened and rare species of the Euphorbiaceae family}

The potential distribution map shows the points sampled and the probability of the presence of the harvested species. Indeed, the analysis of this map shows that Croton membranaceus Müll. Arg has a high probability of occurrence in the Center-East, North-East and East of the country (figures 3). These areas correspond to the probable ecological niche of this species.

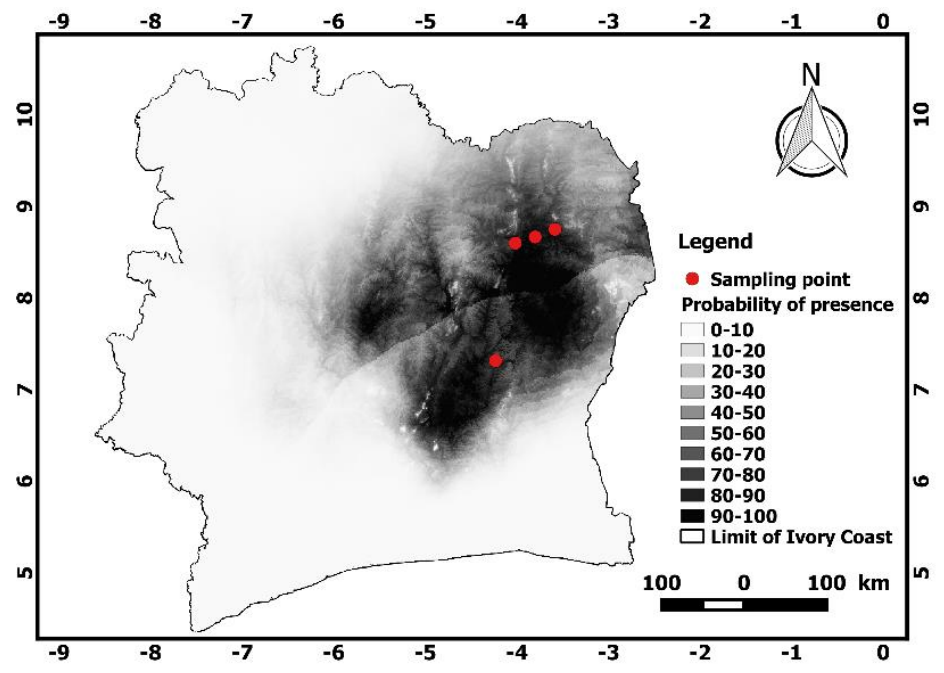

Figure 3: Potential distribution map of Croton membranaceus Müll. Arg.

The environmental variables that most influence the potential distribution of Croton membranaceus Müll. Arg. are the temperature seasonality (bio_4) with a rate of $26.9 \%$ and the seasonality of precipitation (bio_15) with a rate of 21.3 . From a certain threshold $\left(50^{\circ} \mathrm{C}\right.$ for the seasonality of the temperature and $30 \mathrm{~mm}$ ), any increase in the seasonality of the temperature (fig 4) and the seasonality of the precipitation (figure 5), cause a rapid decrease the probability of the presence of Croton membranaceus until it disappears in the environment. The model gives a test AUC value of 0.963 which means that the estimate of the distribution is excellent. The Jackknife test based on AUC data presents the minimum temperature of the coldest month as the major contributing parameter (Figure 6). 


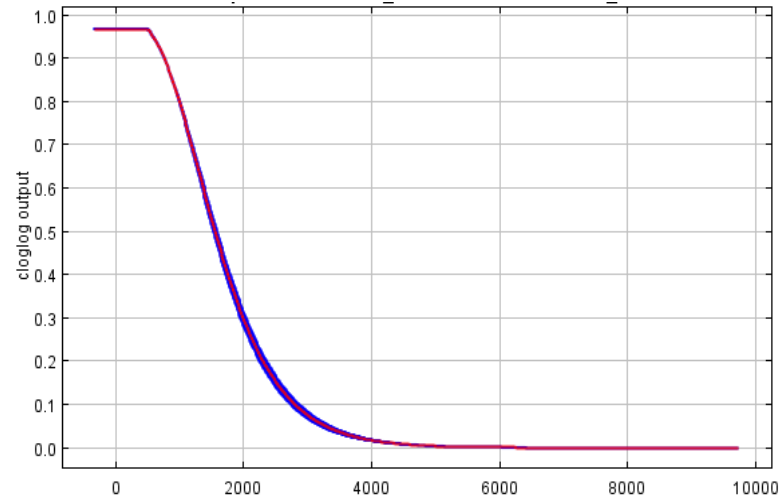

Figure 4: Temperature seasonality (bio4) (degree Celsius)

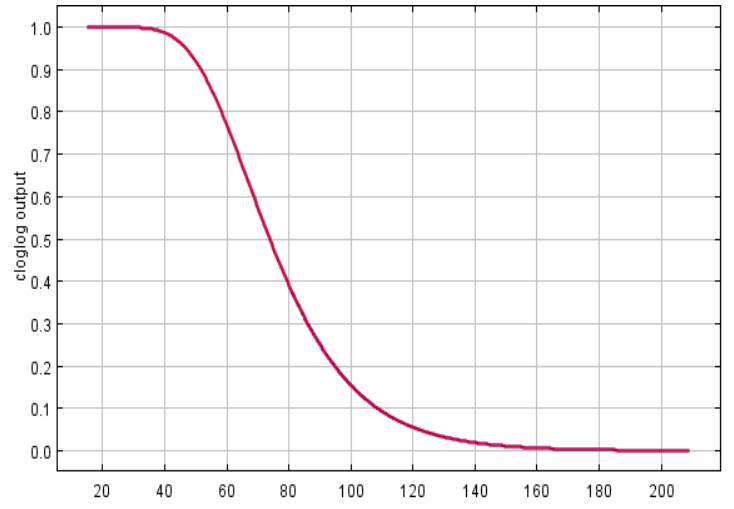

Figure 5: Precipitation seasonality (bio 15) $(\mathrm{mm})$

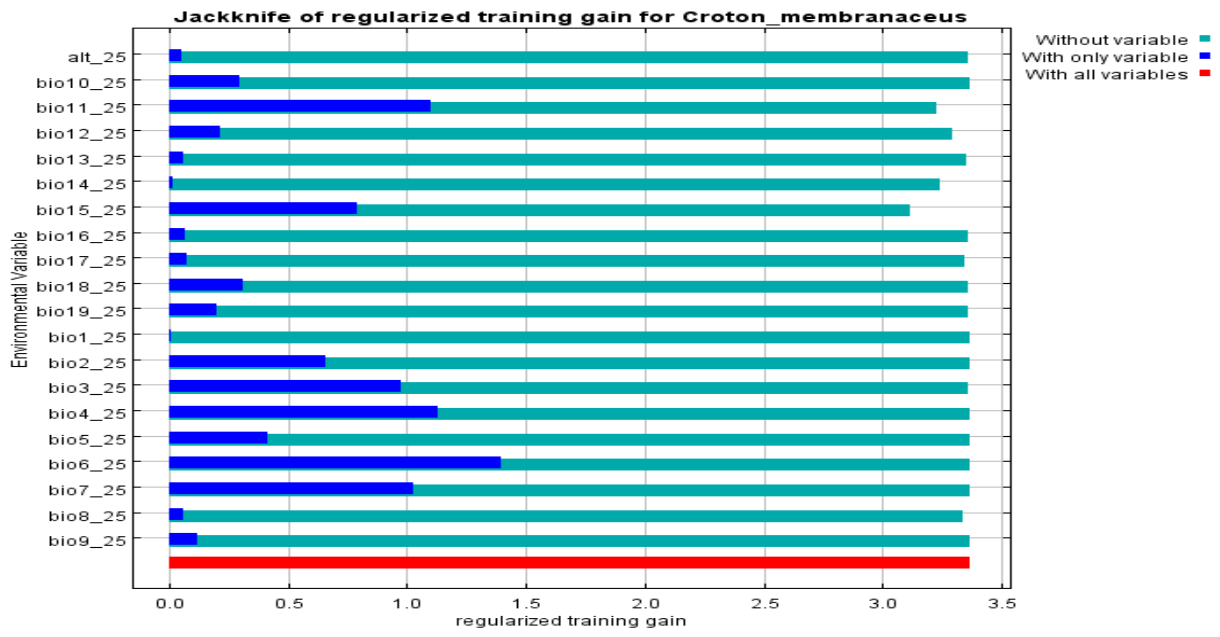

Figure 6: Importance of environmental variables on the distribution of Croton membranaceus Müll. Arg.

The potential distribution map of Croton aubrevilleis hows the points sampled and the probability of occurrence (Figure 7). Indeed, analysis of this map reveals that Croton aubrevillei has a probability of occurrence almost throughout the country. However, the North, North-West and South-West are not favorable for the distribution of Croton aubrevillei. 


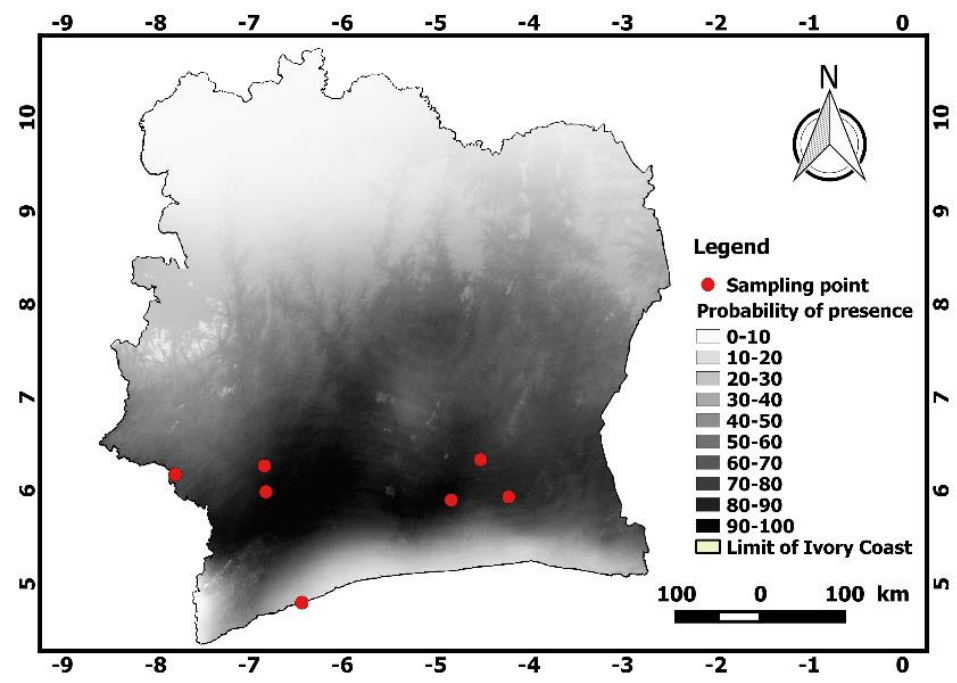

Figure 7: Map of current potential distribution of Croton aubrevilleiJ.Léonard.

The environmental variable that most influences the potential distribution of Croton aubrevillei J. Léonard is the minimum temperature of the coldest month with a percentage of 34.7 (figure 8). From a threshold value $\left(150^{\circ} \mathrm{C}\right)$ of the minimum temperature of the coldest month, we observe a rapid increase in the probability of the presence of Croton aubrevillei in the medium until reaching a stationary value from $250^{\circ} \mathrm{C}$. So, for a good distribution of Croton aubrevillei in a medium, a minimum temperature of the coldest month above $150^{\circ} \mathrm{C}$ is needed.

The AUC test value is 0.960; which means that Maxent's model for this analysis is excellent. The Jackknife test based on AUC data shows the following parameters as being of major contribution: annual temperature variations and the ratio of daily thermal amplitude to annual thermal amplitude (Figure 9). 
Vol. 5, No. 05; 2020

ISSN: 2456-8643

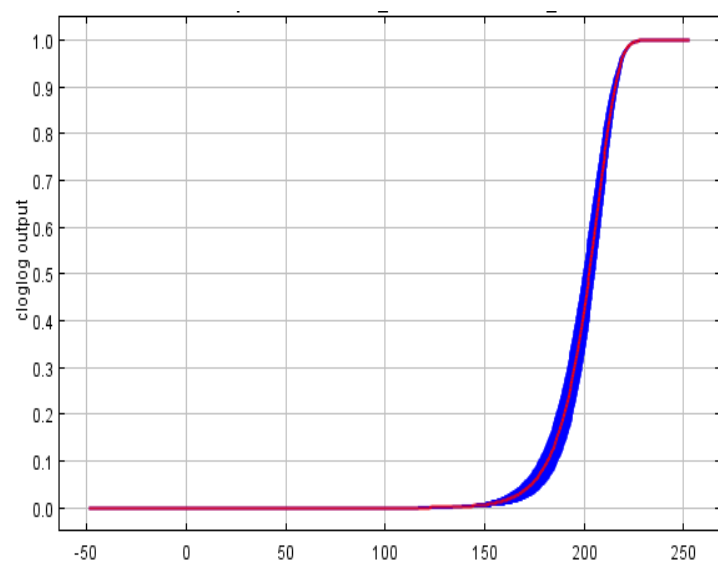

Figure 8: Minimal Temperature of Coldest Month (Bio_6) (degre Celsius)

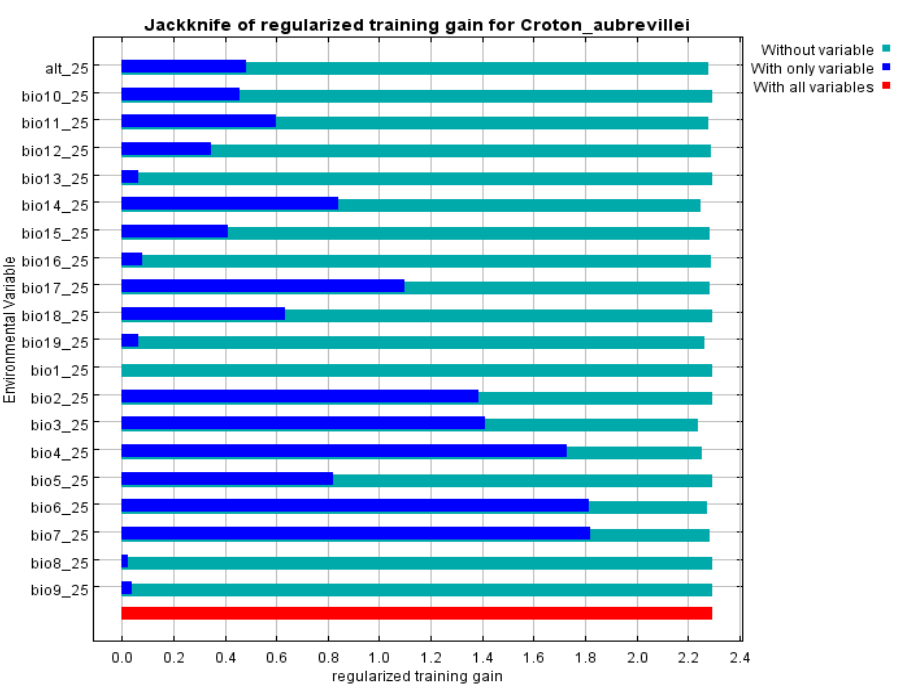

Figure 9: Importance of environmental variables on the current distribution Croton aubrevillei J.

The potential distribution map of Macaranga beillei Prain shows the points sampled and the probability of occurrence (Figures 10). Indeed, the analysis of this map reveals that Macaranga beillei Prain has a probability of occurrence only in the south of the country. The other regions of the country are not favorable to the distribution of Macaranga beillei Prain.

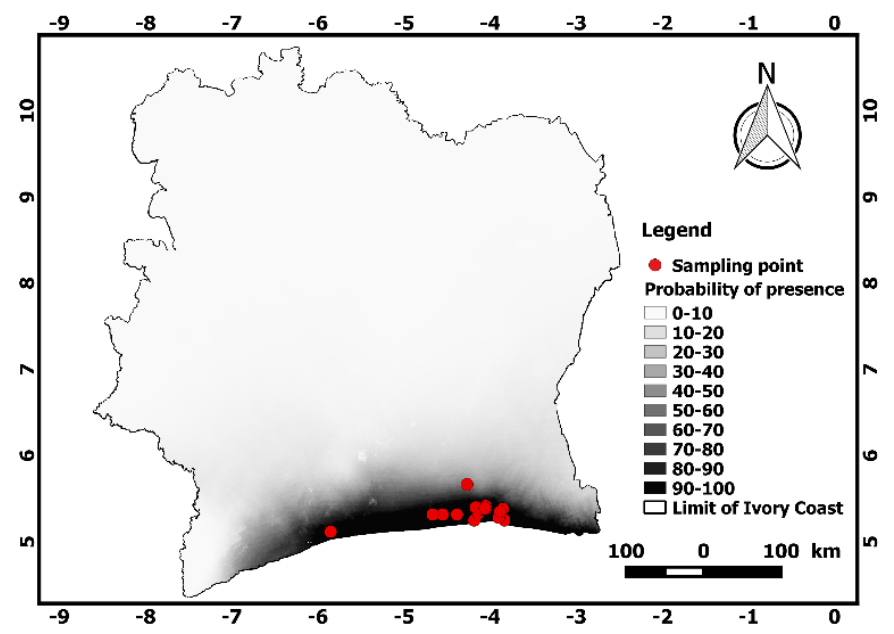

Figure 10: Potential distribution map of MacarangabeilleiPrain

The environmental variables that most influence the potential distribution of Macaranga beillei Prain are the average daily temperature variation (bio_2) with a rate of $18 \%$ and the precipitation of the driest quarter (bio_17) with a rate of 18.1. From a certain threshold of $40^{\circ} \mathrm{C}$, any increase in the average daily variation in temperatures (fig 11) causes a rapid decrease in the probability of the presence of Macaranga beillei Prain until it disappears in the environment for a value of 
$120{ }^{\circ} \mathrm{C}$. Regarding the precipitation of the driest quarter, there is an interval of precipitation of the driest quarter (from 0 to $550 \mathrm{~mm}$ of rain) outside which Macaranga beillei Prain cannot live (figure 12). For a value of $250 \mathrm{~mm}$ of precipitation in the driest quarter, the species (Macaranga beillei) reaches its maximum population in its range.

The model gives a test AUC value of 0.998 which means that the estimate of the distribution is excellent. The Jackknife test based on AUC data presents the average daily temperature variation as the major contributing parameter (Figure 13).

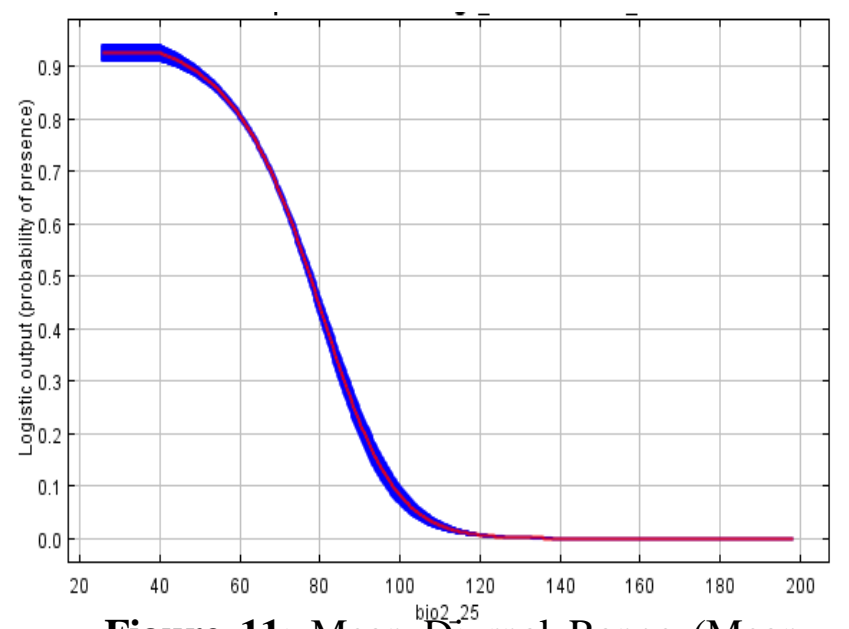

Figure 11: Mean Dio.25urnal Range (Mean of monthly (max temp - min temp)) (bio_2) (degré Celsius)

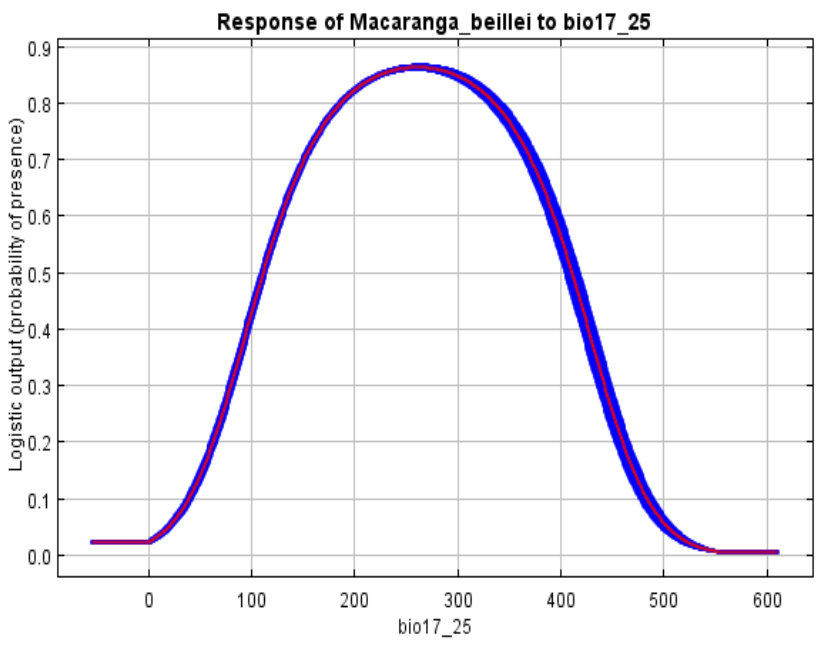

Figure 12: Precipitation of Driest Quarter (bio_17) (mm)

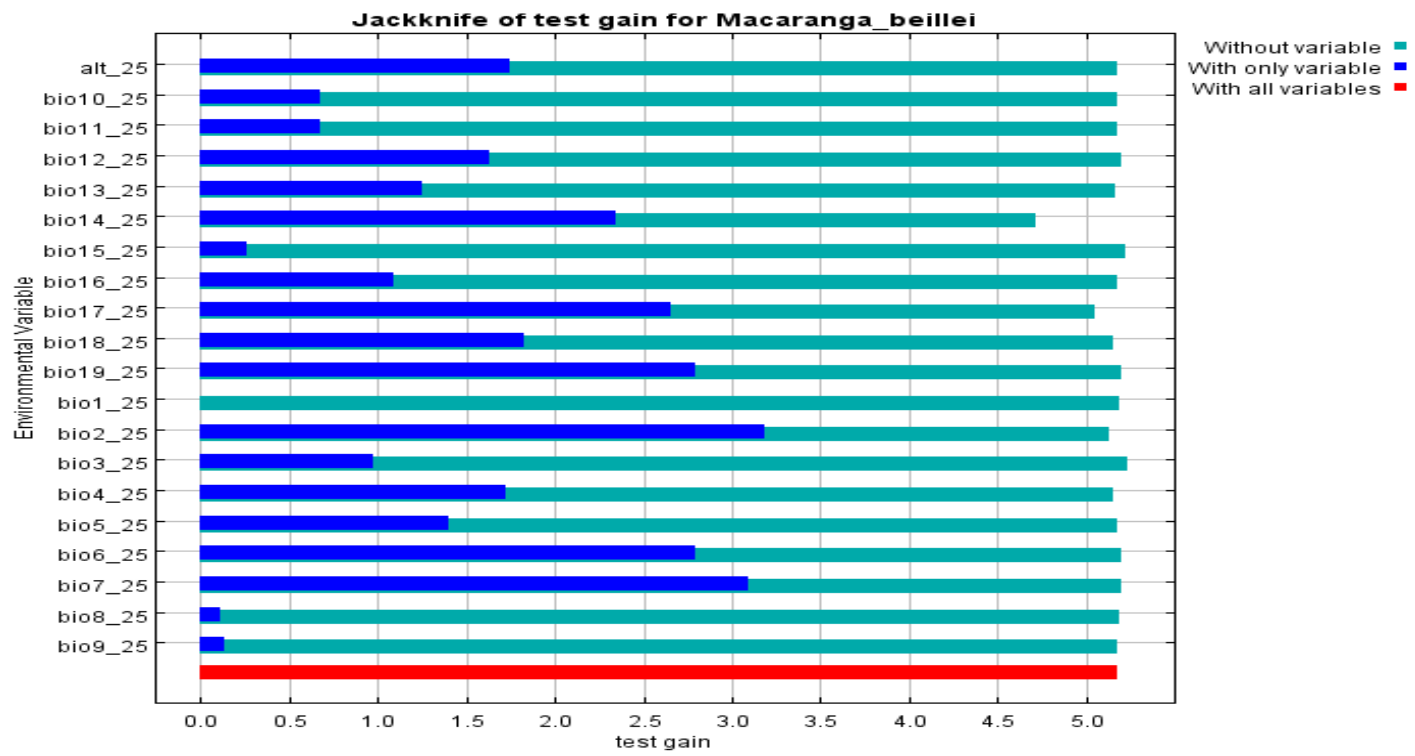

Figure 13: Importance of environmental variables on the distribution of Macaranga beillei Prain 
Vol. 5, No. 05; 2020

ISSN: $2456-8643$

\section{DISCUSSION}

The floristic analysis carried out on all the species of the Euphorbiaceae family of the Ivorian flora, revealed that the Guineo-Congolese (GC) and Guineo-Congolese-Sudano-Zambezian (GCSZ) type species are largely dominant. . This chorological structure as it appears in our results is very comparable to that of dense humid evergreen forests, wooded savannah, trees, shrubs and / or open forest (Kouamé, 1998). According to Sonké (1998), the high proportion of Guinean species in the floristic background of an area is proof that this area does indeed belong to the Guineo-Congolese center of floristic endemism of White (1986). For the biological types, microphanerophytes dominate, which clearly shows that the Euphorbiaceae family contains small and stocky species (Aké Assi, 2001).

This study provides phytogeographic information from the detailed analyzes provided and the establishment of a map of the sampling effort. This information relating to species with particular statuses in occurrence Croton aubrevillei J. Léonard, Croton membranaceus Müll. Arg. and Macaranga beillei Pan should guide new botanical surveys in Côte d'Ivoire. Moreover, Croton aubrevillei J. Léonard has a large ecological amplitude compared to that of Croton membranaceus Müll. Arg. and Macaranga beillei Pan. Indeed, Croton aubrevillei J. Léonard is a shrub present in evergreen and deciduous forests, at low altitude. The evergreen forest is linked to a climate of the equatorial or subequatorial type characterized by a little marked dry season not exceeding 4 months lacking in water, high annual rainfall, greater than approximately 1,700 $\mathrm{mm}$, and an annual water deficit not exceeding $300 \mathrm{~mm}$. Species from this region are able to adapt to divergent edaphic and abiotic factors. This is the case of Croton aubrevillei J. Léonard. However, the vulnerable species status of Croton aubrevillei J. Léonard is mainly due to its use and its range which is strongly threatened by the destruction of its range. This observation was also made by Schmelzer and Gurib-Fakim (2008). Indeed, it emerges from their work that Croton aubrevillei J. Léonard is threatened by the destruction of his environment. Regarding Croton membranaceus Müll. Arg., it is a herbaceous species of shrub savannah. The range of this species is restricted to the center-east, east and northeast. These regions are included in the Sudanese sector. The climate in this region is semi-arid tropical (Sudanese) with a single dry season and an annual water deficit often greater than $900 \mathrm{~mm}$. In addition, the harmattan, a hot and dry north-easterly wind, is responsible for the sharp drop in relative humidity during the dry season; the minimums are less than $20 \%$. and the maximums are between $45 \%$ and $75 \%$. The characteristics of this climate are found especially in the northeast of Côte d'Ivoire (region of Bouna) where rainfall remains sufficiently low (Guillaumet and Adjanohoun, 1957). To these climatic hazards are added the destructive actions of man by bush fires, agriculture and also the misuse of certain plant species. In such a context, the disruption and vulnerability of a species becomes unprecedented. This is the case with Croton membranaceus Müll. Arg. present in such an environment. This observation corroborates that of Lassina et al. (2011), in their work in Burkina Faso. As for Macaranga beillei, it is a species with restricted distribution in the littoral region. Its vulnerability is mainly due to urbanization and agricultural activities. Added to this is its use in traditional medicine (Adjanohoun and Aké Assi, 1979). It should be noted that Macaranga beillei is a species endemic to the Côte d'Ivoire and more precisely endemic to the Coastal region of the Coast. As a result, a low pressure exerted on it or on its area of distribution, whether anthropogenic or environmental, would be enough to put it in a vulnerable state. Indeed, it emerges from this work that vulnerability corresponds to the degree of exposure to the risks of 
Vol. 5, No. 05; 2020

ISSN: $2456-8643$

reduction or disappearance of certain plant species caused by inappropriate harvesting methods in an environment subject to increasing human pressure and climatic variations.

The modeling of the fundamental niches made it possible to observe the potential distribution area of these three species. Indeed, the actual and potential distribution maps of Croton membranaceus Müll. Arg., de Croton aubrevillei J. Léonard and Macaranga beillei Pan make it possible to identify priority areas within the framework of development plans for the benefit of different climatic zones. They constitute a basis for conservation actions for species threatened with extinction, mainly due to anthropogenic influence within the limits of their distribution areas. These actions can only be effective if the potential areas are not overestimated compared to the actual distribution areas (Thiombiano et al., 2006). The different data on the study site can therefore be used to build models from MaxEnt. Better knowledge of its structure and floristic composition is also useful in developing policies for better management of biological resources on a larger scale. The models produced make it possible to bring out the different levels of influence between environmental variables and the dispersion of these species. The MaxEnt model was applied due to the abundance of species in the environment, estimating that their dispersion is still subject to these environmental variables. These factors are respective determining factors in the dispersal of each of these species. It can be seen that Croton aubrevillei J. Léonard is a species sensitive to annual variations in temperature while Croton membranaceus Müll. Arg. Hutch is more sensitive to the seasonality of precipitation and the seasonality of temperature. From this, we can deduce that the existence of a species in a given region is conditioned by several factors including climatic factors.

The seasonal inversion phenomenon and the presence of a more drastic dry season in the North and the significant climatic variations, could be the cause of the limitation to the dispersal of certain species such as Croton membranaceus Müll. Arg. Hutch. Only the maintenance of favorable conditions for long periods can explain their distribution throughout the area. Regarding Macaranga beillei Pan, there is a great sensitivity to the average daily variation in temperature and precipitation in the driest quarter. These factors are respective determining factors in the dispersal of this species. Likewise, for this species, harvests are restricted to the Guinean domain more precisely in the littoral cordon. We can conclude that this is a kind of forest.

Also, it is important to note that biological diversity is strongly threatened because the majority of species of the Euphorbiaceae family in the database such as and especially rare and endangered species have a potential presence in the priority area of conservation. These threats, which considerably affect both ecosystems and the living organisms they shelter, have a decisive effect on the economy and the quality of human life.

\section{INVOLVEMENT IN CONSERVATION}

This chapter highlights the involvement of protected areas in the conservation of biological diversity and ecosystems. In fact, Croton membranaceus Müll. Arg. Hutch, Croton aubrevillei J. Léonard and Macaranga beillei, three vulnerable species, are mostly harvested in national parks or classified forests in Côte d'Ivoire (figure 10). Analysis of the spatial distribution of Croton 
membranaceus Müll. Arg. Hutch shows that it is mostly harvested in Comoé National Park. As for that of Croton aubrevilleiJ. Léonard, it emerges that it was generally collected in classified forests such as classified forests of Monogaga, Mopri, Kinkéné, Bamo, Mando. As for Macarangabeillei Pan, it is mainly harvested in the Banco National Park.

Following these observations, it is indisputable that protected areas have an important implication in the conservation of biological diversity. In fact, most of the protected areas are for certain species like refuge areas. Because of controlled population access and prohibited or controlled harvesting, the species that house these ecosystems can easily multiply outside of climatic hazards. This remark was also made by Jan Bogaert et al (2008).

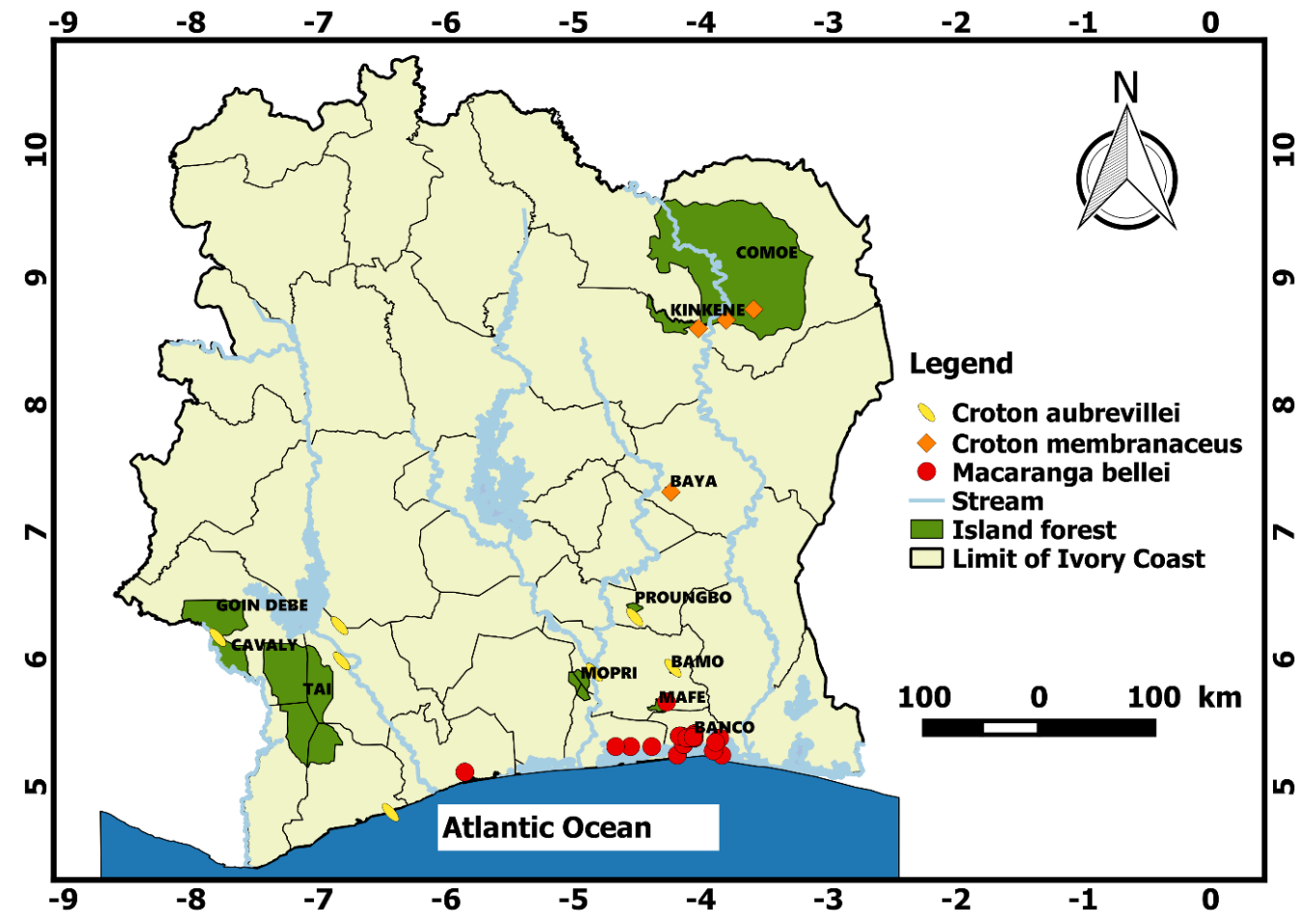

Figure 10: Spatial distribution of Croton membranaceus Müll. Arg. Hutch, Croton aubrevillei J. Léonard and Macaranga beillei Pan

\section{CONCLUSION}

At the end of this work, it emerges that in Côte d'Ivoire, the Euphorbiaceae family occupy an important place in the composition of the flora. The species are variously distributed in the country. Among the species collected, some are endemic to the West African sub-region, and others endemic to Côte d'Ivoire. More than half of the species are of the microphanerophyte type and are found in the Guineo-Congolese zone. 
We were also able to determine four species with special status. These are endemic species, rare in Côte d'Ivoire according to Aké Assi (1998) and according to the IUCN Red List (2019). These various findings allow us to conclude that the distribution and abundance of Euphorbiaceae in the Guineo-Congolese region are determined by various environmental factors such as temperature and precipitation. Thus, the geographical position of Côte d'Ivoire allows it to benefit from very diverse ecosystems for conservation. However, their distributions remain subject to environmental conditions. Therefore, given its multiple importance, it is therefore appropriate for the Ministry of the Environment, the Ministry of Agriculture, environmental structures, research centers and units, universities to conduct a campaign to raise awareness among the population and in particular the peasants, for the promotion and the protection of the species of the Euphorbiaceae family in Côte d'Ivoire for a sustainable use and for the balance of plant biodiversity.

\section{CONFLICT OF INTEREST}

The authors of this manuscript declare that there is no conflict of interest between them.

\section{ACKNOWLEDGEMENTS}

The authors would like to thank the Swiss Center for Scientific Research (CSRS) which made the SIG IVOIRE database available to us. They warmly thank Mr. Cyrille Chatellain and his collaborators who are the authors of this database.

\section{REFERENCES}

AkéAssi L., (1998). Impact de l'exploitation forestière et du développement agricole sur la conservation de la biodiversité biologique en Côte d'Ivoire. Le flamboyant, 46, pp 20-22.

AkéAssi L., (2010). La diversité floristique de quelques régions de l'Afrique de l'ouest: le processus de sa dégradation ébauchée: le cas de la Côte d'Ivoire. In Systématique et Conservation des Plantes Africaines edited by van der Burgt X, van der Maesen J, Onana JM, Royal Botanic Gardens, Kew, 2010: 451-458.

Aké Assi L., (2001). Flore de la Côte d'Ivoire: catalogue systématique, biogéographique et écologique. Vol. (1) Boissiera 57.

Adjanohoun E et Aké Assi L., (1979): Contribution au recessemrnt des plantes médicinales de la Côte d'Ivoire 358p.

Araújo M.B., Pearson R.G., Thuiller W., Erhard M., (2005). Validation of species-climate impact models under climate change. Global Change Biology, 11, 1504 - 1513.

Bouquet A., Debray M., (1974). Les plantes medicinales de la Côte d'Ivoire 231p

Edouard C. C., (1974) Culture In Vitro Des Tissus De Manioc. Université des sciences et techniques de Lille, thèse pour obtenir le grade de docteur de troisième cycle, 103p.

Engler R., Guisan A., Rechsteiner L., (2004). An improved approach for predicting the distribution of rare and endangered species from occurrence and pseudo-absence data. Journal of AppliedEcology, 41, 263-274.

Gautier L., Aké Assi L., Chatelain C., Spichiger R., (1999). Ivoire: a geographic information system for biodiversity management in Ivory Coast. In: Timberlake, J. etKativus, S. (eds.)

African Plants: Biodiversity Taxonomy and uses. Royal Bot. Gardens, Kew. pp. 183-194. Guillaumet J.L. et Adjanohoun E. (1957). La végétation de la côte d'ivoire 261p. 
Haba H., (2008). Etude phytochimique de deux Euphorbiaceae sahariennes Euphorbia guyoniana Boiss et Reut. Euphorbia retusa Forsk. Université El Hadj Lakhdar Batna, facultédes sciences, département de chimie, thèse de doctorat en sciences spécialité: chimie, 305p. Hamilton A.C., Taylor D., (1991). History of climate and forests in tropical Africa during the last 8 million years. Climatic Change, 19, 65-78.

Hijmans R.J., Cameron S.E., Parra J.L., Jones P.G., Jarvis A., (2005). Very high resolution interpolated climate surface for global land areas. International Journal of Climatology, 25, 1965-1978

Jan B., Issouf B., Kouao J. K., Serge S., Jean-Pierre K. Djibu, Dominique C., Elmar R., Charles D. C.` et Marjolein N. V., (2008). Fragmentation of Forest Landscapes in Central Africa: Causes, Consequences and Management 87p.

Koffi K.J., Champluvier D., Danho F.R.N., De Canniere C., Traoré D., Lejoly J., Robbrecht E. \&Bogaert J., (2008). Analyse de la distribution spatiale des Acanthaceae en Afrique Centrale et comparaison avec les théories phytogéographiques de Robyns, White et Ndjele. Sciences \& Nature Vol. $5 \mathrm{~N}^{\circ} 2: 101-110$.

Lassina T., Issaka O., Amadé O. et Adjima T., (2011). Perceptions, usages et vulnérabilité des ressources végétales ligneuses dans le Sud-Ouest du Burkina Faso 278p.

Phillips S.J., Dudik M., Schapire R.E., (2004). A maximum entropy approach to species distribution modelling. In: ACM International Conference Proceeding Series (eds.) Proceedings of the 21st International Conference on Machine Learning: 655-662. New York.

Phillips S.J., Andersonb R.P., Schapired R.E., (2006). Maximum entropy modeling of species geographic distributions. Ecological Modelling, 190, 231-259.

Schmelzer A G.H..Gurib-Fakim, (2008). Ressources végétales de l'Afrique tropicale 11(1)

Plantes médicinales 1, Fondation PROTA / BackhuysPublishers / CTA Wageningen, Pays

Soberon J., (2007). «Grinnellian and Eltonian niches and geographic distributions of species », EcologyLetters, vol. 10, p. 1115 à 1123.

Sonké B. (1998). Etude floristique et structurale des forêts de la réserve de faune du Dja (Cameroun). Thèse de doctorat, université libre de Bruxelles, 267p.

Thiombiano A., Schmidt M., Kreft H., Ginko S., (2006). Influence du gradient climatique sur la distribution des espèces de Combretaceae au Burkina Fasa (Afrique de l'Ouest). Candollea, $61,189-213$.

Vroh BI T. A., N'guessan F. KOUAME1 et Ebagnerin J. TONDOH, (2011). Etude du potentiel de restauration de la diversité floristique des agrosystèmes de bananiers dans la zone de Dabou (Sud Côte d'Ivoire). Sciences \& Nature, Vol. 8, ํำ:37-52

UICN, (2019). Red List of Threatened Species. Available at: http//www.iucnredlist.org.

White F., (1986). La végétation de l'Afrique. Recherche sur les ressources naturelles. ORSTOM-UNESCO, Paris, XX, 384.

ANNEX: Exhaustive list of species of the Euphorbiaceae family recorded in Côte d'Ivoire

Species status: LC: Species of least concern; VU: Vulnerable species; LR / nt: Minor risk species; LR / lc: Species of Least Concern; AA: Rare species according to Aké-Assi. 
International Journal of Agriculture, Environment and Bioresearch

Vol. 5, No. 05; 2020

ISSN: $2456-8643$

\begin{tabular}{|c|c|c|c|c|}
\hline $\mathbf{N}^{\circ}$ & Species & Status & $\begin{array}{l}\text { Chorological } \\
\text { types }\end{array}$ & $\begin{array}{l}\text { Biological } \\
\text { types }\end{array}$ \\
\hline 1 & Acalypha ciliata Forssk. & & $\mathrm{GC}$ & Th \\
\hline 2 & Acalypha racemosa Baill. & & GC & np \\
\hline 3 & Acalypha segetalis Müll. Arg. & & GC-SZ & Th \\
\hline 4 & $\begin{array}{l}\text { Alchornea cordifolia (Schumach. \&Thonn.) Müll. } \\
\text { Arg. }\end{array}$ & & GC-SZ & Lmp (mp) \\
\hline 5 & Alchornea floribunda Müll. Arg. & & GC & $\mathrm{mp}$ \\
\hline 6 & $\begin{array}{l}\text { Alchornea hirtella Benth. f. glabrata (Müll. Arg.) } \\
\text { Pax \&Hoffm. }\end{array}$ & & GC & $\mathrm{mp}$ \\
\hline 7 & Amanoa bracteosa Planch. & & $\mathrm{GC}$ & $\mathrm{mP}$ \\
\hline 8 & Amanoa strobilacea Müll. Arg. & & GC & $\mathrm{mP}$ \\
\hline 9 & Anthostema aubryanum Baill. & & GC & $\mathrm{mP}$ \\
\hline 10 & Anthostema senegalense A. Juss. & & GC & $\mathrm{mP}$ \\
\hline 11 & Antidesma laciniatum Müll. Arg. subsp. laciniatum & & GC & $\mathrm{mp}$ \\
\hline 12 & Antidesma membranaceum Müll. Arg. & & GC & $\mathrm{mp}$ \\
\hline 13 & Antidesma nigricans Tul. & & GCW & np \\
\hline 14 & Antidesma rufescens Tul. & & GC-SZ & $\mathrm{mp}$ \\
\hline 15 & Antidesma venosum Tul. & & SZ & $\mathrm{mp}$ \\
\hline 16 & Argoтиellera macrophylla Pax & & GC & $\mathrm{np}$ \\
\hline 17 & Caperonia serrata ( Turez.) C. Prest & & GC-SZ & Th \\
\hline 18 & $\begin{array}{l}\text { Chrozophora senegalensis (Lam.) A. Juss. ex } \\
\text { Spreng. }\end{array}$ & & SZ & $\mathrm{np}(\mathrm{Ch})$ \\
\hline 19 & Croton aubrevillei J. Léonard & VU & GCW & $\mathrm{mp}$ \\
\hline 20 & Croton dispar N. E. Br & & GCW & Lmp \\
\hline 21 & Croton gratissimus Burch. & & GC & $\mathrm{mp}$ \\
\hline 22 & Croton hirtus L'Hér. & & GC & np (Th) \\
\hline
\end{tabular}


International Journal of Agriculture, Environment and Bioresearch

Vol. 5, No. 05; 2020

ISSN: $2456-8643$

\begin{tabular}{|c|c|c|c|c|}
\hline 23 & Croton lobatus $\mathrm{L}$. & & GC-SZ & Th \\
\hline 24 & Croton macrostachyus Hochst. ex Delile & & GC-SZ & $\mathrm{mp}$ \\
\hline 25 & Croton membranaceus Müll. Arg. & VU/AA & GC & np \\
\hline 26 & Croton mubango Müll. Arg. & & GC & $\mathrm{mp}$ \\
\hline 27 & Croton nigritanus Scott-Elliot & & GC & $\mathrm{np}$ \\
\hline 28 & Croton penduliflorus Hutch. & & GC & $\mathrm{mp}$ \\
\hline 29 & Croton pseudopulchellus Pax & & SZ & $\mathrm{mp}$ \\
\hline 30 & Croton scarciesii Scott-Elliot & & GCW & $\mathrm{np}$ \\
\hline 31 & Crotonogyne caterviflora N. E. Br. & & GCW & $\mathrm{np}$ \\
\hline 32 & Crotonogyne chevalieri (Beille) Keay & & GCW & $\mathrm{np}$ \\
\hline 33 & Crotonogynopsis akeassi J. Léonard & & GCW & np \\
\hline 34 & Dalechampia ipomoeifolia Benth. & & GC & Lmp \\
\hline 35 & $\begin{array}{l}\text { Discoclaoxylon hexandrum (Müll. Arg) Pax \& K. } \\
\text { Hoffm. }\end{array}$ & & GC & $\mathrm{mp}$ \\
\hline 36 & Discoglypremna caloneura $(\mathrm{Pax})$ Prain & & GC & $\mathrm{mP}$ \\
\hline 37 & Erythrococca Africana Baill. & & GC & $\mathrm{mp}$ \\
\hline 38 & Erythrococca anomala ( Juss. ex Poir.) Prain & & GC & $\mathrm{np}$ \\
\hline 39 & Euphorbia baga A. Chev & & SZ & Hpy \\
\hline 40 & Euphorbia convolvuloides Hochst. ex Benth. & & SZ & $\mathrm{Ch}$ \\
\hline 41 & Euphorbia deightonii Croizat & & GC & $\mathrm{mp}$ \\
\hline 42 & Euphorbia forsskalii J. Gay & & GC-SZ & $\mathrm{Ch}$ \\
\hline 43 & Euphorbia glaucophylla Poir. & & GC & $\mathrm{Ch}$ \\
\hline 44 & Euphorbia glomerifera ( Millsp.) L. C. Wheeler & & $\mathrm{GC}$ & Th \\
\hline 45 & Euphorbia grandifolia Haw. & & $\mathrm{GC}$ & $\mathrm{mP}$ \\
\hline 46 & Euphorbia heterophylla L. & & GC & Th \\
\hline
\end{tabular}


International Journal of Agriculture, Environment and Bioresearch

Vol. 5, No. 05; 2020

ISSN: $2456-8643$

\begin{tabular}{|c|c|c|c|c|}
\hline 47 & Euphorbia hirta L. & & GC-SZ & $\mathrm{Ch}$ \\
\hline 48 & Euphorbia kouandenensis Beille & & SZ & H(Hру) \\
\hline 49 & Euphorbia macrophylla Pax & & SZ & np \\
\hline 50 & Euphorbia polycnemoides Hochst. ex boiss. & & SZ & Th \\
\hline 51 & Euphorbia prostrata Aiton & & GC-SZ & $\mathrm{Ch}$ \\
\hline 52 & Euphorbia thymifolia $\mathrm{L}$. & & GC-SZ & $\mathrm{Ch}$ \\
\hline 53 & Euphorbia unispina N. E. Br. & & SZ & $\mathrm{mp}$ \\
\hline 54 & Excoecaria grahamii Stapf & & GC-SZ & np (Hрy) \\
\hline 55 & Excoecaria guineensis (Benth.) Müll. Arg. & & GC-SZ & $\mathrm{mp}$ \\
\hline 56 & Flueggea virosa (Roxb. ex Willd.) Voigt & & GC-SZ & $\mathrm{np}$ \\
\hline 57 & Grossera vignei Hoyle & & GC & $\mathrm{mp}$ \\
\hline 58 & Hymenocardia acida Tul. & & GC-SZ & $\mathrm{mp}$ \\
\hline 59 & Hymenocardia heudelotii Müll. Arg. & & GC-SZ & $\mathrm{mp}$ \\
\hline 60 & Hymenocardia lyrata Tul. & & GCW & $\mathrm{mp}$ \\
\hline 61 & Jatropha atacorensis A. Chev. & & SZ & H ( Нpy) \\
\hline 62 & Jatropha curcas L. & & GC-SZ & $\mathrm{np}$ \\
\hline 63 & Jatropha gossypiifolia L. & & GC-SZ & $\mathrm{np}$ \\
\hline 64 & Macaranga beillei Prain & V & $\mathrm{GCi}$ & $\mathrm{mp}(\mathrm{Lmp})$ \\
\hline 65 & Macaranga barteri Müll. Arg. & & GC & $\mathrm{mp}$ \\
\hline 66 & Macaranga heterophylla Müll. Arg. & & GC & $\mathrm{mp}$ \\
\hline 67 & Macaranga heudelotii Baill. & & GC & $\mathrm{mp}$ \\
\hline 68 & Macaranga hurifolia Beille & & GC & $\mathrm{mp}$ \\
\hline 68 & Macaranga spinosa Müll. Arg. & & GC & $\mathrm{mp}$ \\
\hline 69 & Macaranga schweinfurthii Pax & & GC & $\mathrm{mp}$ \\
\hline 70 & Mallotus oppositifolius (Geiseler) Müll. Arg. var. & & GC-SZ & $\mathrm{mp}$ \\
\hline
\end{tabular}


International Journal of Agriculture, Environment and Bioresearch

Vol. 5, No. 05; 2020

ISSN: $2456-8643$

\begin{tabular}{|c|c|c|c|c|}
\hline & oppositifolius & & & \\
\hline 71 & Mallotus subulatus Müll. Arg. & & GC & $\mathrm{np}$ \\
\hline 72 & Manniophyton fulvum Müll. Arg. & & GC & Lmp \\
\hline 73 & Mareya micrantha (Benth.) Müll. Arg. & & GC & $\mathrm{mp}$ \\
\hline 74 & Margaritaria discoidea (Baill.) Webster & & GC-SZ & $\mathrm{mp}$ \\
\hline 75 & Martretia quadricornis Beille & & GC & $\mathrm{mp}$ \\
\hline 76 & Micrococca mercurialis (L.) Benth. & & GC & $\mathrm{np}$ \\
\hline 77 & Plesiatropha paniculata $(\mathrm{Pax})$ Breteler & & GC & $\mathrm{mp}$ \\
\hline 78 & Necepsia afzelii Prain subsp. Afzelii & & GC & $\mathrm{mp}$ \\
\hline 79 & Neoboutonia mannii Benth. \& Hook.f. & & GC & $\mathrm{mp}$ \\
\hline 80 & Oldfieldia africana Benth. \&Hook. f. & & GC & $\mathrm{mP}$ \\
\hline 81 & Pycnocoma angustifolia Prain & & GCW & $\mathrm{np}$ \\
\hline 82 & Pycnocoma macrophylla Benth. & & GC & $\mathrm{mp}$ \\
\hline 83 & $\begin{array}{l}\text { Ricinodendron heudelotii (Baill.) Pierre ex Heckel } \\
\text { subsp. africanum (Müll. Arg.) J. Léonard }\end{array}$ & & GC & $\mathrm{mP}$ \\
\hline 84 & Sapium aubrevillei Léandri & & GCi & $\mathrm{mp}$ \\
\hline 85 & $\begin{array}{l}\text { Sclerocroton carterianus (J.Léonard) Kruijt \& } \\
\text { Roebers }\end{array}$ & VU & GCW & $\mathrm{np}$ \\
\hline 86 & Microstachys dalzielii (Hutch.) Esser & & SZ & $\mathrm{np}$ (Нру) \\
\hline 87 & Sapium ellipticum ( Hochst.) Pax & & GC-SZ & $\mathrm{mp}$ \\
\hline 88 & Sebastiania chamaelea (L.) Müll. Arg. & & SZ & $\mathrm{np}$ \\
\hline 89 & $\begin{array}{l}\text { Spondianthus preussii Engl. subsp. glaber (Engl.) J. } \\
\text { Léonard \& Nkounkou }\end{array}$ & & SZ & $\mathrm{mP}$ \\
\hline 90 & Suregada ivorensis (Aubrév. \&Pellegr.) J. Léonard & & GCW & $\mathrm{mp}$ \\
\hline 91 & Suregada occidentalis (Hoyle) Croizat & & GC & $\mathrm{mp}$ \\
\hline
\end{tabular}


International Journal of Agriculture, Environment and Bioresearch

Vol. 5, No. 05; 2020

ISSN: $2456-8643$

\begin{tabular}{|l|l|l|l|}
\hline 92 & $\begin{array}{l}\text { Tetrorchidum didymostemon (Baill.) Pax \& K. } \\
\text { Hoffm. }\end{array}$ & GC & mp \\
\hline 93 & Thecacoris stenopetala (Müll. Arg.) Müll. Arg. & GC & np \\
\hline 94 & Tragia benthamii Baker & GC & Lnp \\
\hline 95 & Tragia chevalieri Beille & GC & Lnp \\
\hline 96 & Tragia laminularis Müll. Arg. & GC & Lnp \\
\hline 97 & Tragia polygonoides Prain & GCi & Lnp \\
\hline 98 & Tragia senegalensis Müll & GC-SZ & np \\
\hline 99 & Tragia spathulata Benth. & GC-SZ & Lnp \\
\hline 100 & Tragia tenuifolia Benth. & GC & Lnp \\
\hline 101 & Tragia vogelii Keay & SZ & Lnp \\
\hline 102 & Tragia wildemanii Beille & SZ & H (Hpy) \\
\hline
\end{tabular}

